\title{
How the Aromatic 4-Membered Hydrido-Bridged Copper Rings Respond to Successive Nucleophilic Attack?
}

\author{
C.A. Tsipis ${ }^{*}$ and N.D. Charistos
}

\author{
Laboratory of Applied Quantum Chemistry, Faculty of Chemistry, Aristotle University of Thessaloniki, 54124 Thessa- \\ loniki, Greece
}

\begin{abstract}
Electronic structure calculations (B3LYP/6-311+G**) predict that nucleophilic attack of the aromatic cyclo$\mathrm{Cu}_{4}(\mu-\mathrm{H})_{4}$ ring yields ligand-stabilized tetranuclear $\mathrm{Cu}_{4}$ clusters formulated as cyclo- $\mathrm{Cu}_{4}(\mu-\mathrm{H})_{4} \mathrm{Nuc}_{\mathrm{n}}\left(\mathrm{n}=1-4 ; \mathrm{Nuc}=\mathrm{N}_{2}\right.$, $\mathrm{CO}, \mathrm{H}_{2} \mathrm{O}, \mathrm{NH}_{3}$ and $\mathrm{PH}_{3}$ ). Depending on the number of added nucleophiles, the tetranuclear $\mathrm{Cu}_{4}$ clusters adopt planar, bent or $3 \mathrm{D}$ tetrahedral geometries. These molecules exhibit aromatic character, which is primarily due to $4 s$ and $3 d$ cyclic electron delocalization over the $\mathrm{Cu}_{4}$ framework ( $s$ and $d$-orbital aromaticity). The aromaticity of the novel ligand stabilized tetranuclear $\mathrm{Cu}_{4}$ clusters was verified by a number of established criteria of aromaticity. In particular, the nucleusindependent chemical shift, NICS(0) and NICS(1) and their out-of-plane components $\operatorname{NICS}_{\mathrm{zz}}(0), \mathrm{NICS}_{\mathrm{zz}}(1)$ and the NICS scan pictures are indicative for the aromaticity of the planar, bent and tetrahedral $\mathrm{Cu}_{4}$ clusters. The effect of the substituents on the aromatic character of the $\mathrm{Cu}_{4}$ clusters is also a main concern of the present work. It was found that increasing the number of the attacking nucleophiles increases the diatropic response of the aromatic tetranuclear $\mathrm{Cu}_{4}$ clusters. Moreover, the aromaticity of the 3D structures (spherical aromaticity) is higher than the aromaticity of the planar and bent structures. The effect of the coordinated nucleophiles, Nuc, on the stability, geometry, electronic structure and bonding mode of the cyclo- $\mathrm{Cu}_{4}(\mu-\mathrm{H})_{4} \mathrm{Nuc}_{\mathrm{n}}$ molecules is also thoroughly discussed.
\end{abstract}

Keywords: Aromaticity, DFT calculations, Four-member copper rings, nucleophilic attack, metallaromaticity.

\section{INTRODUCTION}

Recently, we have communicated on a new class of cyclic copper(I) hydrides (hydrocoppers) formulated as $\mathrm{Cu}_{\mathrm{n}}(\mu$ $\mathrm{H})_{\mathrm{n}}(\mathrm{n}=3-6)$ as the cyclic hydrocarbon analogues in the diverse tapestry of inorganic chemistry [1]. The choice of the copper(I) hydrides was based on the well known tendency of copper(I) centers to cluster together in a variety of organocopper(I) compounds involving even the alkyl groups as bridging ligands, a representative example being the cyclic $\mathrm{Cu}_{4} \mathrm{R}_{4}$ tetramer [2-11]. The cyclic hydrocoppers(I) and some of their substituted derivatives were predicted to be stable species with a perfectly planar configuration, thus expanding the borders of inorganic chemistry into the realm of organic chemistry by building molecules containing bonds that are characterized by a common ring-shaped electron density, more commonly seen in organic molecules, with new properties and chemical reactivity. Moreover, these findings may not only expand the aromaticity concept in all-metal systems with structures resembling those of the aromatic hydrocarbons, but may also indicate whole classes of new inorganic aromatic species (substituted derivatives) resulting upon substitution of the $\mathrm{H}$ atoms by other groups such as alkyls ( $\mathrm{R})$ and aryls $(\mathrm{Ar})$, halides $(\mathrm{X})$, amido $\left(\mathrm{NR}_{2}\right)$, hydroxide $(\mathrm{OH})$ and alkoxides (OR) etc.

The structures of $\mathrm{HCN}-\mathrm{Cu}_{\mathrm{n}}(\mathrm{n}=1-3)$ clusters were determined through high resolution infrared spectroscopy [12]. All complexes were found to be bound to the nitrogen end of

\footnotetext{
*Address correspondence to this author at the Laboratory of Applied Quantum Chemistry, Faculty of Chemistry, Aristotle University of Thessaloniki, 54124 Thessaloniki, Greece; E-mail: tsipis@chem.auth.gr
}

the HCN molecule and on the "atop site" of the copper cluster. The $\mathrm{HCN}-\mathrm{Cu}$ interactions changes from a strong van der Waals bond in $\mathrm{n}=1$ to a partially covalent bond in $\mathrm{HCN}$ $\mathrm{Cu}_{3}$. Very recently [13] the important intermediate phenylcopper complexes $\left[\mathrm{C}_{6} \mathrm{H}_{5} \mathrm{Cu}_{\mathrm{m}}\right]^{-}(\mathrm{m}=1-3]$, which are produced from the reactions between copper metal clusters formed by laser ablation and the benzene molecules seeded in argon carrier gas, were studied by photoelectron spectroscopy (PES) and density functional theory (DFT).

Herein we address a number of important issues related to the response of the aromatic cyclo- $\mathrm{Cu}_{4}(\mu-\mathrm{H})_{4}$ molecule towards successive nucleophilic attack by a series of nucleophiles, Nuc, yielding ligand-stabilized tetranuclear $\mathrm{Cu}_{4}$ clusters formulated as cyclo- $\mathrm{Cu}_{4}(\mu-\mathrm{H})_{4} \mathrm{Nuc}_{\mathrm{n}}\left(\mathrm{n}=1-4 ; \mathrm{Nuc}=\mathrm{N}_{2}\right.$, $\mathrm{CO}, \mathrm{H}_{2} \mathrm{O}, \mathrm{NH}_{3}$ and $\mathrm{PH}_{3}$ ). The molecular and electronic structures, stabilities and bonding features of these novel ligandstabilized tetranuclear $\mathrm{Cu}_{4}$ clusters are thoroughly presented, using electronic structure calculation methods at the DFT level of theory.

\section{THEORETICAL METHODS}

In view of the good performance of density functional theory (DFT), we were instigated to perform DFT calculations at the B3LYP level of theory on all of the compounds we studied using the GAUSSIAN03 program suite [14]. The geometries of all species were fully optimized at the Becke's 3 -Parameter hybrid functional $[15,16]$ combined with the Lee-Yang-Parr [17] correlation functional abbreviated as B3LYP level of density functional theory, using the 6$311+\mathrm{G}(\mathrm{d}, \mathrm{p})$ basis set. Full geometry optimization was performed for each structure using Schlegel's analytical gradient method [18], and the attainment of the energy minimum 
was verified by calculating the vibrational frequencies that result in absence of imaginary eigenvalues. The vibrational modes and the corresponding frequencies are based on a harmonic force field. This was achieved with the SCF convergence on the density matrix of at least $10^{-9}$ and the rms force less than $10^{-4}$ au. All bond lengths and bond angles were optimized to better than $0.001 \AA$ and $0.1^{\circ}$, respectively. The computed electronic energies were corrected to constant pressure and $298 \mathrm{~K}$, for zero point energy (ZPE) differences and for the contributions of the translational, rotational and vibrational partition functions. Magnetic shielding tensors have been computed with the GIAO (gauge-including atomic orbitals) DFT method [19] as implemented in the GAUSSIAN03 series of programs [14] employing the B3LYP level of theory. Nucleus-Independent Chemical Shifts (NICS) values were computed at the B3LYP/6-311+G(d,p) level according to the procedure described by Schleyer et al. [20]. The magnetic shielding tensor elements was calculated for a ghost atom located at the center of the ring. Negative (diatropic) NICS values indicate aromaticity, while positive (paratropic) values imply antiaromaticity.

\section{RESULTS AND DISCUSSION}

\subsection{Structures of the cyclo- $\mathrm{Cu}_{4}(\mu-\mathrm{H})_{4} \mathrm{Nuc}_{\mathrm{n}}(\mathrm{n}=1-4$; $\mathrm{Nuc}=$ $\mathrm{N}_{2}, \mathrm{CO}, \mathrm{H}_{2} \mathrm{O}, \mathrm{NH}_{3}$ and $\mathrm{PH}_{3}$ ) Molecules}

Stationary point geometries of the cyclo- $\mathrm{Cu}_{4}(\mu-\mathrm{H})_{4} \mathrm{Nuc}_{\mathrm{n}}$ ( $\mathrm{n}=1-4 ; \mathrm{Nuc}=\mathrm{N}_{2}, \mathrm{CO}, \mathrm{H}_{2} \mathrm{O}, \mathrm{NH}_{3}$ and $\mathrm{PH}_{3}$ ) molecules computed at the B3LYP/6-311+G(d,p) level of theory are presented in Figs. (1) and (2).

Perusal of Figs. (1) and (2) reveals that the addition of the nucleophiles, Nuc $\left(\mathrm{Nuc}=\mathrm{N}_{2}, \mathrm{CO}, \mathrm{H}_{2} \mathrm{O}, \mathrm{NH}_{3}\right.$ and $\left.\mathrm{PH}_{3}\right)$ to the $\mathrm{Cu}(\mathrm{I})$ metal centers of the parent cyclo- $\mathrm{Cu}_{4}(\mu-\mathrm{H})_{4}\left(D_{4 \mathrm{~h}}\right)$ molecule in some cases alters the planar cyclo- $\mathrm{Cu}_{4}(\mu-\mathrm{H})_{4}$ stereochemistry affording three-dimensional (3D) structures with $C_{2 \mathrm{v}}, C_{3 \mathrm{v}}$ and $\mathrm{T}_{\mathrm{d}}$ symmetries. In the case of the addition of two carbonyl ligands in 1,2-positions of the ring, ring opening occurs by insertion of the hydride ligand between the two copper atoms bearing the carbonyl ligands, yielding complex 7. The addition of one and two nucleophiles, Nuc, changes the rectangular $\mathrm{Cu}_{4}$ core structure ( $D_{4 \mathrm{~h}}$ point group) of the parent molecule to a rhombic core structure having $C_{2 \mathrm{v}}$ and $D_{2 \mathrm{~h}}$ symmetry, respectively.

Nucleophilic attack of the cyclo- $\mathrm{Cu}_{4}(\mu-\mathrm{H})_{4}$ species by one and two $\mathrm{N}_{2}$ nucleophiles does not alter the planarity of the cyclo- $\mathrm{Cu}_{4}(\mu-\mathrm{H})_{4}$ cluster, yielding the cyclo- $\mathrm{Cu}_{4}\left(\mu_{2}\right.$ $\mathrm{H})_{4}\left(\eta^{1}-\mathrm{N}_{2}\right), \quad 1$ and cyclo- $\mathrm{Cu}_{4}\left(\mu_{2}-\mathrm{H}\right)_{4}\left(\eta^{1}-\mathrm{N}_{2}\right)_{2}, 2$, complexes, having $C_{2 \mathrm{v}}$ and $D_{2 \mathrm{~h}}$ symmetry, respectively. Dinitrogen is coordinated to copper(I) centers in an end-on coordination mode $\left(\eta^{1}-\mathrm{N}_{2}\right)$. Moreover, in complex $\mathbf{2}$ the distance between the copper atoms, which have not attacked by the nucleophile, is $2.855 \AA$, indicating weak intermetallic interactions between these two copper atoms as well. On the other hand, nucleophilic attack of the cyclo- $\mathrm{Cu}_{4}(\mu-\mathrm{H})_{4}$ species by three and four $\mathrm{N}_{2}$ nucleophiles strongly alters the planarity of the $\mathrm{Cu}_{4}(\mu-\mathrm{H})_{4}$ core structure, yielding the 3D structures $\mathrm{Cu}_{4}\left(\mu_{2}-\right.$ $\mathrm{H})_{4}\left(\eta^{1}-\mathrm{N}_{2}\right)_{3}, 3$ and $\mathrm{Cu}_{4}\left(\mu_{2}-\mathrm{H}\right)_{4}\left(\eta^{1}-\mathrm{N}_{2}\right)_{4}, 4$, with $C_{3 \mathrm{v}}$ and $T_{\mathrm{d}}$ symmetry, respectively. It is important to be noticed that in the $3 \mathrm{D}$ structures the hydride ligands are triply-bridged facecapping the tetrahedral structure.
A variety of structures are obtained upon coordination of one to four CO ligands with the copper(I) metal centers of the parent cyclo- $\mathrm{Cu}_{4}(\mu-\mathrm{H})_{4}$ cluster. Thus, coordination of one $\mathrm{CO}$ ligand yields the cyclo- $\mathrm{Cu}_{4}\left(\mu_{2}-\mathrm{H}\right)_{4}\left(\eta^{1}-\mathrm{CO}\right)$, 5, cluster belonging to $C_{2 \mathrm{v}}$ point group. The addition of the first $\mathrm{CO}$ ligand to one of the $\mathrm{Cu}(\mathrm{I})$ metal centers results in the shortening of the $\mathrm{Cu}-\mathrm{Cu}$ bond distance between the non attacked $\mathrm{Cu}(\mathrm{I})$ metal centers by $0.021 \AA$, while the adjacent $\mathrm{Cu}-\mathrm{Cu}$ bonds are elongated by $0.143 \AA$ with respect to the $\mathrm{Cu}-\mathrm{Cu}$ bond distance of the parent cyclo- $\mathrm{Cu}_{4}(\mu-\mathrm{H})_{4}$ molecule $(2.440$ $\AA)$.

Three minima were located on the potential energy surface (PES) of the $\mathrm{Cu}_{4} \mathrm{H}_{4}(\mathrm{CO})_{2}$ system. The global minimum corresponds to the planar structure $6\left(D_{2 \mathrm{~h}}\right)$, with the two CO ligands in 1,3-positions. Noteworthy is the relatively short $\mathrm{Cu} \cdots \mathrm{Cu}$ distance of $2.689 \AA$ between the non attacked $\mathrm{Cu}(\mathrm{I})$ centers in the rhombic "all-metal" ring indicating the existence of intermetallic interactions between these copper atoms as well. Conformer 7, with the two CO ligands in 1,2positions corresponds to a local minimum $6.9 \mathrm{kcal} / \mathrm{mol}$ higher in energy than the global minimum 6. In conformer 7 , the $\mathrm{Cu} \cdots \mathrm{Cu}$ distance between the copper atoms bearing the CO ligands has dramatically increased to $3.036 \AA$, illustrating the ring opening at this point and the two copper atoms are only symmetrically bridged by a hydride ligand. The third isomer 8, corresponding to a local minimum at 27.3 $\mathrm{kcal} / \mathrm{mol}$ higher in energy than the global minimum, adopts a $3 \mathrm{D}$ configuration with $C_{2 \mathrm{v}}$ symmetry. All bridging hydride ligands are triply bridging ligands face-capping the tetrahedral $\mathrm{Cu}_{4}\left(\mu_{3}-\mathrm{H}\right)_{4}\left(\eta^{1}-\mathrm{CO}\right)_{2}$ structure. Three minima were also located on the PES of the $\mathrm{Cu}_{4} \mathrm{H}_{4}(\mathrm{CO})_{3}$ system. The global minimum, corresponding to conformer 9, adopts a bent structure of $C_{\mathrm{s}}$ symmetry. The $\mathrm{Cu}-\mathrm{Cu}-\mathrm{Cu}-\mathrm{Cu}$ dihedral angle is $147.9^{\circ}$, while the bent around the $\mathrm{Cu}^{\cdots} \mathrm{Cu}$ hinge forms weakly bonding $\mathrm{Cu} \cdots \mathrm{Cu}$ interactions $(\mathrm{Cu} \cdots \mathrm{Cu}$ distance of $2.711 \AA$ ). Conformer 10, adopting a 3D tetrahedral structure of $C_{3 \mathrm{v}}$ symmetry, corresponds to a local minimum 9.6 $\mathrm{kcal} / \mathrm{mol}$ higher in energy with respect to the global minimum 9. The planar conformer $\mathbf{1 1}$ belonging to $C_{2 \mathrm{v}}$ point group corresponds to a saddle point $\left(v=35.5 i \mathrm{~cm}^{-1}\right), 2.2$ $\mathrm{kcal} / \mathrm{mol}$ higher in energy with respect to the global minimum. Following the imaginary frequency and re-optimizing the structure the global minimum is achieved. Finally, for the $\mathrm{Cu}_{4} \mathrm{H}_{4}(\mathrm{CO})_{4}$ species we were able to locate three minima on the PES corresponding to conformers with tetrahedral, bent and planar structures. In the tetrahedral structure, 12, with $T_{\mathrm{d}}$ symmetry, corresponding to the global minimum, the $\mathrm{Cu}-\mathrm{Cu}$ bond distances are $2.536 \AA$, while all hydride ligands are triply bridging face-capping the tetrahedral structure. The bent structure, 13, possessing $D_{2 \mathrm{~d}}$ symmetry is a local minimum $7.3 \mathrm{kcal} / \mathrm{mol}$ higher in energy. The $\mathrm{Cu}-\mathrm{Cu}-\mathrm{Cu}-\mathrm{Cu}$ dihedral angle in $\mathbf{1 3}$ is $105.3^{\circ}$. The planar conformer, 14, of $D_{4 \mathrm{~h}}$ symmetry corresponds to a saddle point $\left(v=20.4 i \mathrm{~cm}^{-1}\right) 14.4$ $\mathrm{kcal} / \mathrm{mol}$ higher in energy with respect to the global minimum. Following the imaginary frequency the local minimum, 13, is obtained.

Analogous is the response of the cyclo- $\mathrm{Cu}_{4}(\mu-\mathrm{H})_{4}$ species towards the nucleophilic attack by the $\mathrm{H}_{2} \mathrm{O}, \mathrm{NH}_{3}$ and $\mathrm{PH}_{3}$ nucleophiles (Fig. 2). Coordination of one and two $\mathrm{H}_{2} \mathrm{O}$ ligands does not alter the planar configuration of the clusters. 


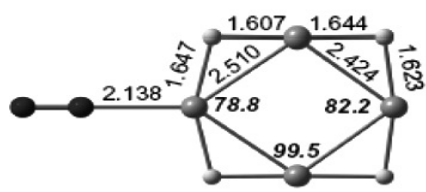

$1\left(C_{2 \mathrm{v}}\right)$ cyclo- $-\mathrm{Cu}_{4}\left(\mu_{2}-\mathrm{H}\right) 4\left(\eta^{1}-\mathrm{N}_{2}\right)$

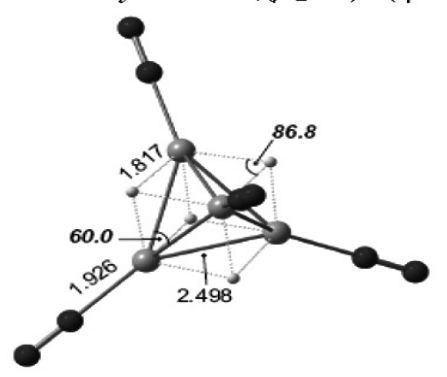

$4\left(T_{\mathrm{d}}\right)$ cyclo- $\mathrm{Cu}_{4}\left(\mu_{3}-\mathrm{H}\right) 4\left(\eta^{1}-\mathrm{N}_{2}\right)_{4}$

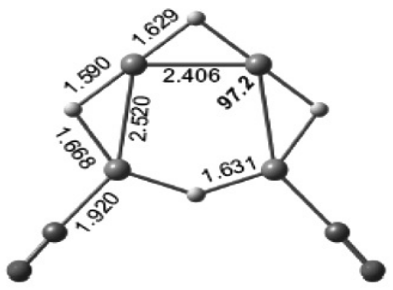

$7\left(C_{2 \mathrm{v}}\right)$

cyclo- $\mathrm{Cu}_{4}\left(\mu_{2}-\mathrm{H}\right) 4\left(\eta^{1}-\mathrm{CO}\right)_{2}$

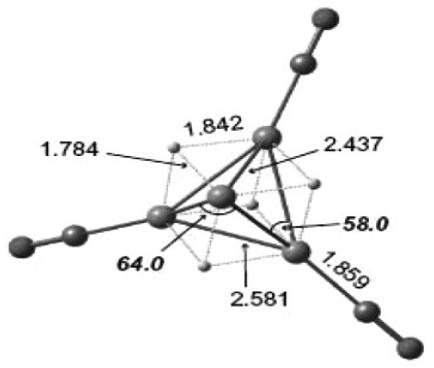

$10\left(C_{3 \mathrm{v}}\right)$

cyclo $-\mathrm{Cu}_{4}\left(\mu_{3}-\mathrm{H}\right) 4\left(\eta^{1}-\mathrm{CO}\right)_{3}$

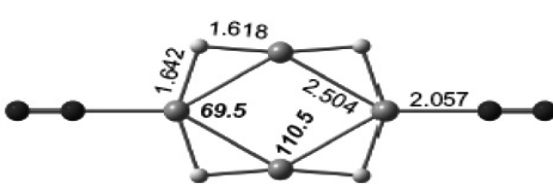

$2\left(D_{2 h}\right)$ cyclo $-\mathrm{Cu}_{4}\left(\mu_{2}-\mathrm{H}\right) 4\left(\eta^{1}-\mathrm{N}_{2}\right)_{2}$

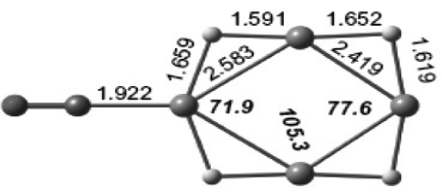

$5\left(C_{2 \mathrm{v}}\right)$ cyclo- $\mathrm{Cu}_{4}\left(\mu_{2}-\mathrm{H}\right) 4\left(\eta^{1}-\mathrm{CO}\right)$

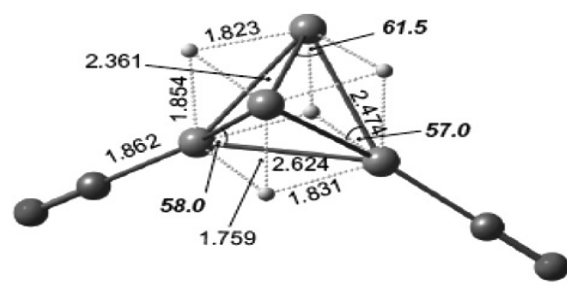

$8\left(C_{2 v}\right)$

cyclo- $\mathrm{Cu}_{4}\left(\mu_{3}-\mathrm{H}\right) 4\left(\eta^{1}-\mathrm{CO}\right)_{2}$

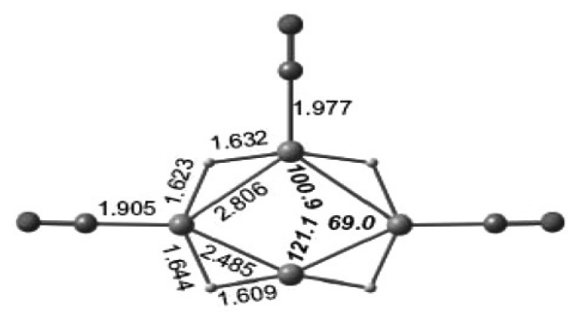

$11\left(C_{2 v}\right)$ cyclo- $\mathrm{Cu}_{4}\left(\mu_{2}-\mathrm{H}\right) 4\left(\eta^{1}-\mathrm{CO}\right)_{3}$

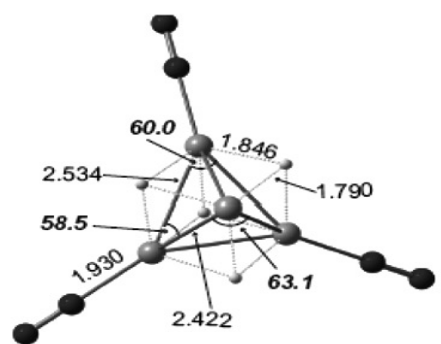

$3\left(C_{3 \mathrm{v}}\right)$ cyclo- $-\mathrm{Cu}_{4}\left(\mu_{2}-\mathrm{H}\right) 4\left(\eta^{1}-\mathrm{N}_{2}\right)_{3}$

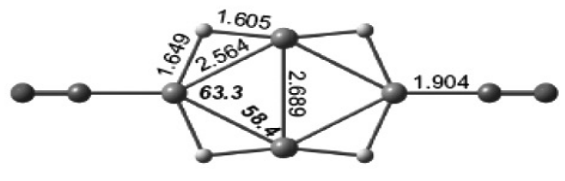

$6\left(D_{2 h}\right)$ cyclo $-\mathrm{Cu}_{4}\left(\mu_{2}-\mathrm{H}\right) 4\left(\eta^{1}-\mathrm{CO}\right)_{2}$

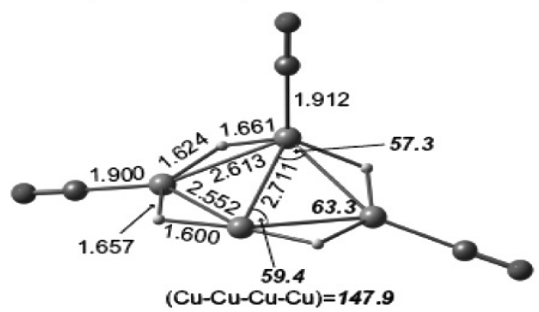

$9\left(C_{\mathrm{s}}\right)$ cyclo $-\mathrm{Cu}_{4}\left(\mu_{2}-\mathrm{H}\right) 4\left(\eta^{1}-\mathrm{CO}\right)_{3}$

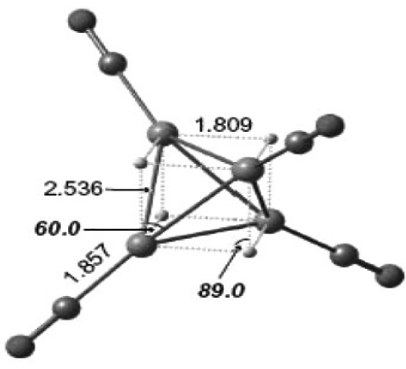

$12\left(T_{\mathrm{d}}\right)$ cyclo- $\mathrm{Cu}_{4}\left(\mu_{3}-\mathrm{H}\right) 4\left(\eta^{1}-\mathrm{CO}\right)_{3}$

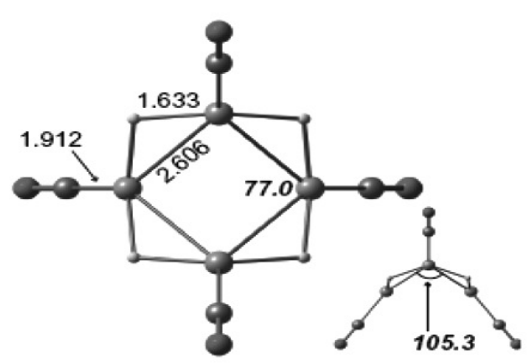

$13\left(D_{2 \mathrm{~d}}\right)$

cyclo- $\mathrm{Cu}_{4}\left(\mu_{3}-\mathrm{H}\right) 4\left(\eta^{1}-\mathrm{CO}\right)_{4}$

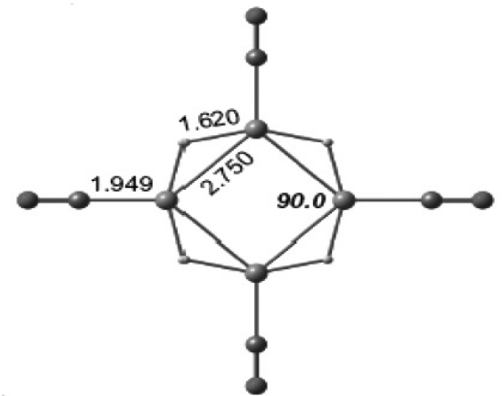

$14\left(D_{4 \mathrm{~h}}\right)$ cyclo- $\mathrm{Cu}_{4}\left(\mu_{2}-\mathrm{H}\right) 4\left(\eta^{1}-\mathrm{CO}\right)_{4}$

Fig. (1). Equilibrium geometries (bond lengths in Angstroms angles in deg) of the stationary points located on the PES of the $\mathrm{Cu}_{4}\left(\mathrm{I}_{-} \mathrm{H}\right)_{4} \mathrm{Nucn}$ $\left(\mathrm{n}=1-4 ; \mathrm{Nuc}=\mathrm{N}_{2}, \mathrm{CO}\right)$ molecules, computed at the B3LYP/6-311+G(d,p) level. 


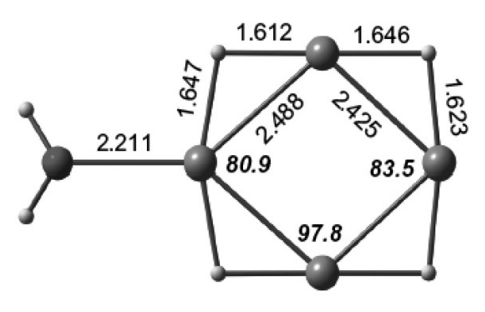

$15\left(C_{\mathrm{s}}\right)$

cyclo- $\mathrm{Cu}_{4}\left(\mu_{2}-\mathrm{H}\right)_{4}\left(\mathrm{OH}_{2}\right)$

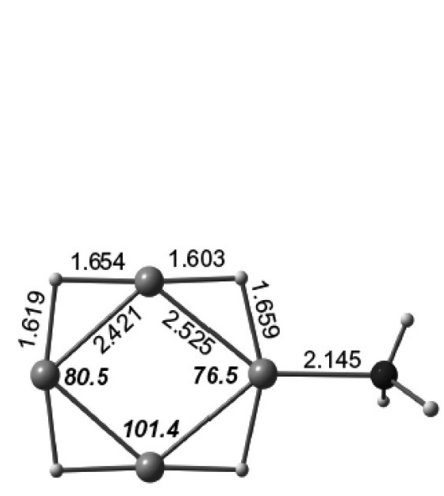

$18\left(C_{\mathrm{s}}\right)$

cyclo- $\mathrm{Cu}_{4}\left(\mu_{2}-\mathrm{H}\right)_{2}\left(\mu_{3}-\mathrm{H}\right)_{2}\left(\mathrm{NH}_{3}\right)$$$
18\left(C_{s}\right)
$$

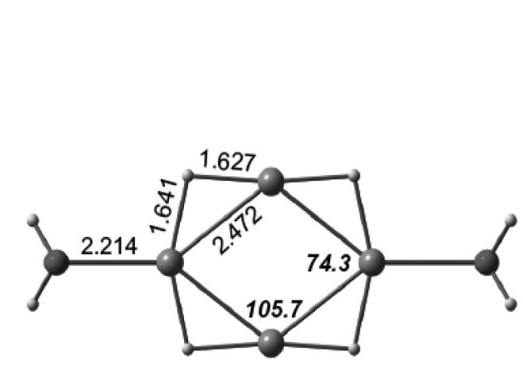

$16\left(C_{2 h}\right)$

cyclo $-\mathrm{Cu}_{4}\left(\mu_{2}-\mathrm{H}\right)_{4}\left(\mathrm{OH}_{2}\right)_{2}$

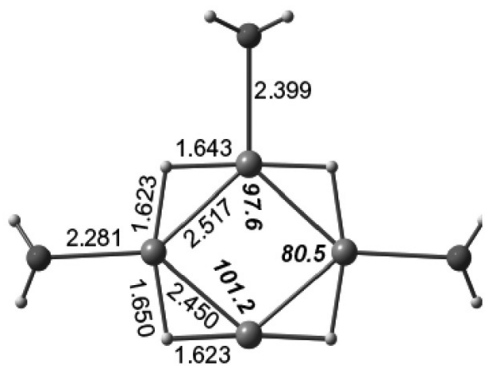

$17\left(C_{\mathrm{s}}\right)$

cyclo $-\mathrm{Cu}_{4}\left(\mu_{2}-\mathrm{H}\right)_{4}\left(\mathrm{OH}_{2}\right)_{3}$

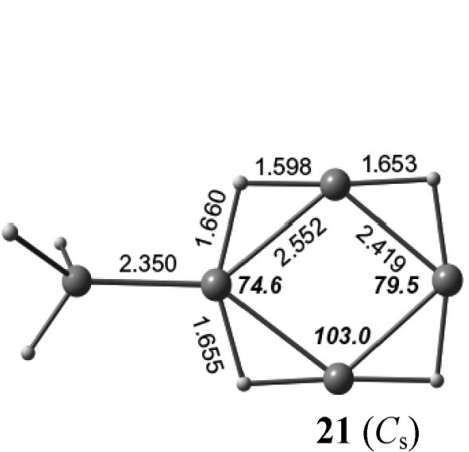

cyclo- $\mathrm{Cu}_{4}\left(\mu_{3}-\mathrm{H}\right)_{4}\left(\mathrm{PH}_{3}\right)$

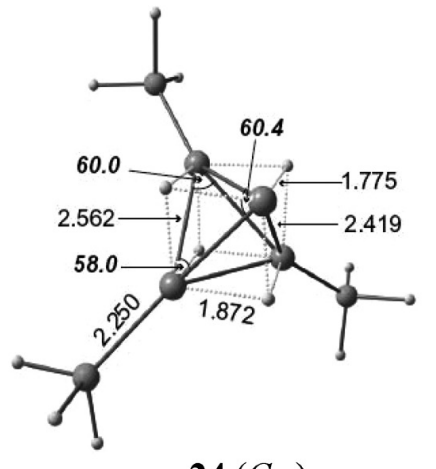

$$
24\left(C_{3 \mathrm{v}}\right)
$$

cyclo- $\mathrm{Cu}_{4}\left(\mu_{3}-\mathrm{H}\right)_{4}\left(\mathrm{PH}_{3}\right)_{3}$

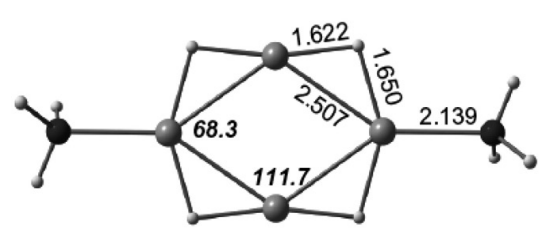

$19\left(C_{2 \mathrm{~h}}\right)$

cyclo $-\mathrm{Cu}_{4}\left(\mu_{2}-\mathrm{H}\right)_{4}\left(\mathrm{NH}_{3}\right)_{2}$

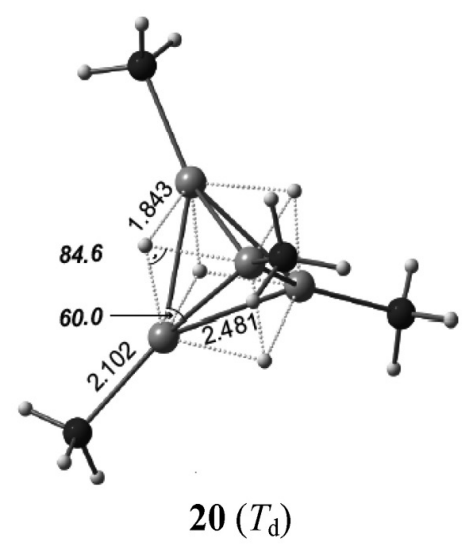

cyclo- $\mathrm{Cu}_{4}\left(\mu_{3}-\mathrm{H}\right)_{4}\left(\mathrm{NH}_{3}\right)_{4}$

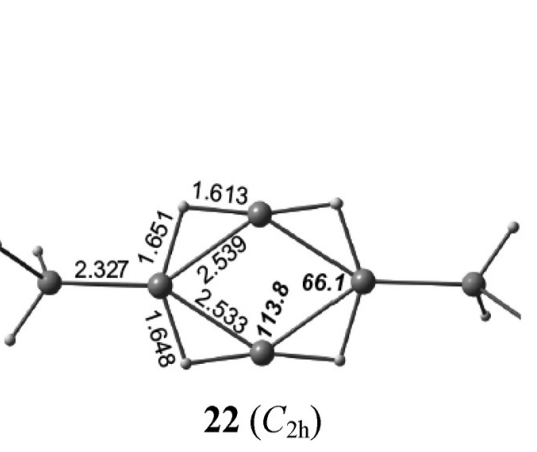

cyclo- $\mathrm{Cu}_{4}\left(\mu_{2}-\mathrm{H}\right)_{4}\left(\mathrm{PH}_{3}\right)_{2}$

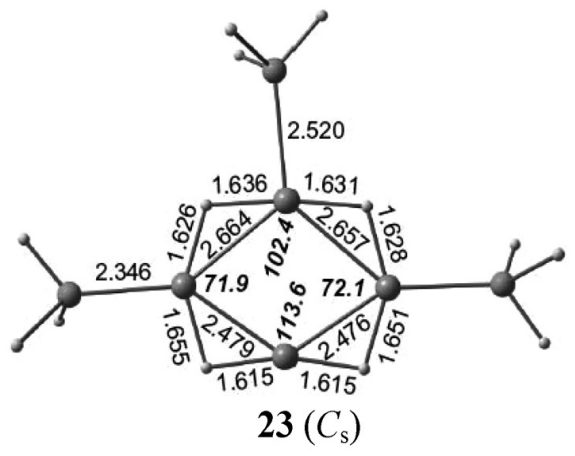

$23\left(C_{\mathrm{s}}\right)$

cyclo- $\mathrm{Cu}_{4}\left(\mu_{2}-\mathrm{H}\right)_{4}\left(\mathrm{PH}_{3}\right)_{2}$

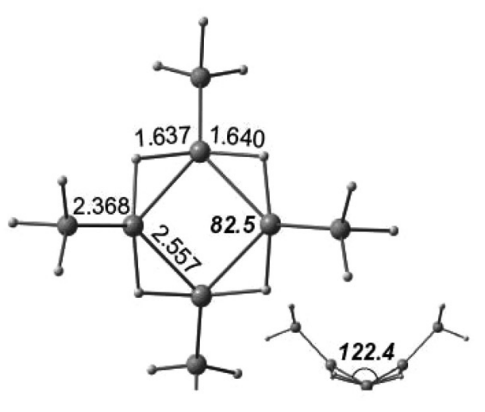

$25\left(D_{2 \mathrm{~d}}\right)$

cyclo- $\mathrm{Cu}_{4}\left(\mu_{2}-\mathrm{H}\right)_{4}\left(\mathrm{PH}_{3}\right)_{4}$

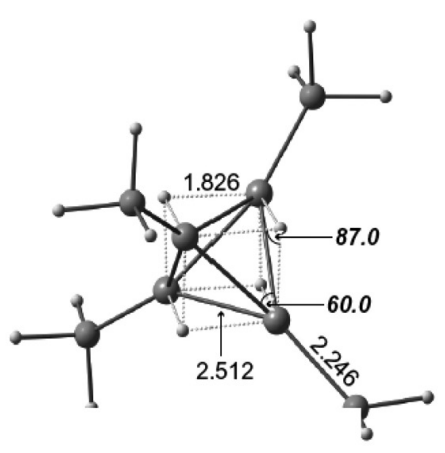

$26\left(T_{\mathrm{d}}\right)$

cyclo- $\mathrm{Cu}_{4}\left(\mu_{3}-\mathrm{H}\right)_{4}\left(\mathrm{PH}_{3}\right)_{4}$

Fig. (2). Equilibrium geometries (bond lengths in Angstroms angles in deg) of the stationary points located on the $\mathrm{PES}$ of the $\mathrm{Cu}_{4}\left(\mathrm{I}_{-} \mathrm{H}\right) 4 \mathrm{Nuc}$ (n $=1-4 ; \mathrm{Nuc}=\mathrm{OH}_{2}, \mathrm{NH}_{3}, \mathrm{PH}_{3}$ ) molecules, computed at the B3LYP/6-311+G(d,p) level. 
In the cyclo- $\mathrm{Cu}_{4}(\mu-\mathrm{H})_{4}\left(\mathrm{OH}_{2}\right), \mathbf{1 5}$, cluster the hydrogen atoms of the coordinated $\mathrm{H}_{2} \mathrm{O}$ molecule are oriented out of the molecular plane, thereby the symmetry of the molecule is the $C_{\mathrm{s}}$. The same holds also true for the cyclo- $\mathrm{Cu}_{4}(\mu-\mathrm{H})_{4}\left(\mathrm{OH}_{2}\right)_{2}$ species, 16 of $C_{2 \mathrm{~h}}$ symmetry where the hydrogen atoms of the coordinated $\mathrm{H}_{2} \mathrm{O}$ molecules are oriented on both sides of the molecular plane. Another conformer of $C_{2 \mathrm{v}}$ symmetry with the hydrogen atoms of the coordinated $\mathrm{H}_{2} \mathrm{O}$ molecules oriented on one side of the molecular plane corresponds to a local minimum $0.04 \mathrm{kcal} / \mathrm{mol}$ higher in energy than the global minimum, 16. Notice that only the cyclo- $\mathrm{Cu}_{4}(\mu$ $\mathrm{H})_{4}\left(\mathrm{OH}_{2}\right)_{2}$ conformers with the coordinated $\mathrm{H}_{2} \mathrm{O}$ molecules in 1,3-positions were located in the PES. The global minimum of the $\mathrm{Cu}_{4} \mathrm{H}_{4}\left(\mathrm{OH}_{2}\right)_{3}$ system corresponds to the planar structure $17\left(C_{\mathrm{s}}\right)$, while a 3D tetrahedral structure, $18\left(C_{3}\right)$ is a local minimum at $26.4 \mathrm{kcal} / \mathrm{mol}$ higher in energy. Attempts to locate a minimum in the PES of the $\mathrm{Cu}_{4} \mathrm{H}_{4}\left(\mathrm{OH}_{2}\right)_{4}$ system were unsuccessful.

Nucleophilic attack of the cyclo- $\mathrm{Cu}_{4}(\mu-\mathrm{H})_{4}$ species by one molecule of the $\mathrm{NH}_{3}$ nucleophile, affords the cyclo$\mathrm{Cu}_{4}(\mu-\mathrm{H})_{4}\left(\mathrm{NH}_{3}\right), \mathbf{1 9}$, cluster, which keeps the planarity of the parent cyclo- $\mathrm{Cu}_{4}(\mu-\mathrm{H})_{4}$ molecule. Notice that one of the hydrogen atoms of the coordinated $\mathrm{NH}_{3}$ ligand is coplanar with the molecular plane. The second $\mathrm{NH}_{3}$ ligand is coordinated to a $\mathrm{Cu}(\mathrm{I})$ center in 1,3-positions affording the cyclo- $\mathrm{Cu}_{4}(\mu$ $\mathrm{H})_{4}\left(\mathrm{NH}_{3}\right)_{2}$, 20, cluster having $C_{2 \mathrm{~h}}$ symmetry. Attempts to locate a minimum in the PES of the $\mathrm{Cu}_{4} \mathrm{H}_{4}\left(\mathrm{NH}_{3}\right)_{3}$ system were unsuccessful. The fully substituted $\mathrm{Cu}_{4}(\mu-\mathrm{H})_{4}\left(\mathrm{NH}_{3}\right)_{4}$, 21, cluster adopts a $3 \mathrm{D}$ tetrahedral stereochemistry belonging to $T_{\mathrm{d}}$ point group. In the $T_{\mathrm{d}}$ structure all bridging hydride ligands are triply bridging face-capping the tetrahedron.

Finally, the successive nucleophilic attack of the aromatic parent cyclo- $\mathrm{Cu}_{4}(\mu-\mathrm{H})_{4}$ molecule by the $\mathrm{PH}_{3}$ nucleophile yields mono-, di-, tri- and tetra-substituted derivatives. The mono-substituted derivative, 22, retains the planarity of the parent cyclo- $\mathrm{Cu}_{4}(\mu-\mathrm{H})_{4}$ species, but the perfect square planar $\mathrm{Cu}_{4}$ core of the parent molecule is transformed to a rhombic "all-metal" core. In the di-substituted derivative, 23, of $C_{2 \mathrm{~h}}$ symmetry, the two $\mathrm{PH}_{3}$ ligands occupy the 1,3positions in the rhombic $\mathrm{Cu}_{4}$ structural core. Two trisubstituted derivatives were located on the PES of the $\mathrm{Cu}_{4} \mathrm{H}_{4}\left(\mathrm{PH}_{3}\right)_{3}$ system. The global minimum corresponds to a planar structure, 24, having $C_{\mathrm{s}}$ symmetry, while a $3 \mathrm{D}$ structure, 25, of $C_{3 \mathrm{v}}$ symmetry is a local minimum $14.9 \mathrm{kcal} / \mathrm{mol}$ higher in energy. For the tetra-substituted cyclo- $\mathrm{Cu}_{4}(\mu$ $\mathrm{H})_{4}\left(\mathrm{PH}_{3}\right)_{4}$ derivative the global minimum corresponds to the bent structure, 26, belonging to $D_{2 \mathrm{~d}}$ point group, while the $3 \mathrm{D}$ structure, 27, with $T_{\mathrm{d}}$ symmetry is a local minimum only $1.7 \mathrm{kcal} / \mathrm{mol}$ higher in energy. Notice again the triply bridging hydride ligands face-capping the tetrahedron.

\subsection{Stability of the cyclo- $\mathrm{Cu}_{4}(\mu-\mathrm{H})_{4} \mathrm{~L}_{\mathbf{n}}\left(\mathrm{n}=1-4 ; \mathrm{Nuc}=\mathrm{N}_{2}\right.$, $\mathrm{CO}, \mathrm{H}_{2} \mathrm{O}, \mathrm{NH}_{3}$ and $\mathrm{PH}_{3}$ ) Molecules}

The stability of the cyclo- $\mathrm{Cu}_{4}(\mu-\mathrm{H})_{4} \mathrm{Nuc}_{\mathrm{n}}(\mathrm{n}=1-4 ; \mathrm{Nuc}=$ $\mathrm{N}_{2}, \mathrm{CO}, \mathrm{H}_{2} \mathrm{O}, \mathrm{NH}_{3}$ and $\left.\mathrm{PH}_{3}\right)$ molecules are investigated using the following fragmentation pattern:

cyclo- $\mathrm{Cu}_{4}(\mu-\mathrm{H})_{4} \mathrm{Nuc}_{\mathrm{n}} \rightarrow$ cyclo- $\mathrm{Cu}_{4}(\mu-\mathrm{H})_{4}+\mathrm{nNuc}$ The calculated binding energies are compiled in Table $\mathbf{1 .}$
Table 1. Total Electronic Energy $E$ (in Hartrees) and Binding Energies $\Delta E_{1}, \Delta E_{2}$ and $\Delta E_{3}$ (in $\mathrm{kcal} / \mathrm{mol}$ ) of the cyclo$\mathrm{Cu}_{4}(\mu-\mathrm{H})_{4} \mathrm{Nuc}_{\mathrm{n}}\left(\mathrm{n}=1-4 ; \mathrm{Nuc}=\mathrm{N}_{2}, \mathrm{CO}, \mathrm{H}_{2} \mathrm{O}, \mathrm{NH}_{3}\right.$ and $\mathrm{PH}_{3}$ ) Molecules Computed at the B3LYP/6$311+G(d, p)$ Level

\begin{tabular}{|c|c|c|c|}
\hline Cluster & $\begin{array}{l}\text { Point } \\
\text { Group }\end{array}$ & $\begin{array}{c}\Delta E_{1}^{\mathrm{a}} \\
{[\mathrm{kcal} / \mathrm{mol}]}\end{array}$ & $\begin{array}{c}\Delta E_{1} / \mathbf{n} \\
{[\mathrm{kcal} / \mathrm{mol}]}\end{array}$ \\
\hline cyclo- $-\mathrm{Cu}_{4}(\mu-\mathrm{H})_{4}\left(\mathrm{~N}_{2}\right), \mathbf{1}$ & $C_{2 \mathrm{v}}$ & -0.8 & -0.8 \\
\hline cyclo- $-\mathrm{Cu}_{4}(\mu-\mathrm{H})_{4}\left(\mathrm{~N}_{2}\right)_{2}, \mathbf{2}$ & $D_{2 \mathrm{~h}}$ & -2.3 & -1.2 \\
\hline $\mathrm{Cu}_{4}(\mu-\mathrm{H})_{4}\left(\mathrm{~N}_{2}\right)_{3}, \mathbf{3}$ & $C_{3 \mathrm{v}}$ & -25.1 & -8.4 \\
\hline $\mathrm{Cu}_{4}(\mu-\mathrm{H})_{4}\left(\mathrm{~N}_{2}\right)_{4}, \mathbf{4}$ & $T_{\mathrm{d}}$ & -33.7 & -8.4 \\
\hline cyclo- $\mathrm{Cu}_{4}(\mu-\mathrm{H})_{4}(\mathrm{CO}), \mathbf{5}$ & $C_{2 \mathrm{v}}$ & -10.2 & -10.2 \\
\hline cyclo- $\mathrm{Cu}_{4}(\mu-\mathrm{H})_{4}(\mathrm{CO})_{2}, \mathbf{6}$ & $D_{2 \mathrm{~h}}$ & -23.6 & -11.8 \\
\hline cyclo- $-\mathrm{Cu}_{4}(\mu-\mathrm{H})_{4}(\mathrm{CO})_{2}, 7$ & $C_{2 \mathrm{v}}$ & -16.8 & -8.4 \\
\hline $\mathrm{Cu}_{4}(\mu-\mathrm{H})_{4}(\mathrm{CO})_{2}, \mathbf{8}$ & $C_{2 \mathrm{v}}$ & -42.8 & -21.4 \\
\hline cyclo- $\mathrm{Cu}_{4}(\mu-\mathrm{H})_{4}(\mathrm{CO})_{3}, 9$ & $C_{\mathrm{s}}$ & -28.0 & -9.3 \\
\hline $\mathrm{Cu}_{4}(\mu-\mathrm{H})_{4}(\mathrm{CO})_{3}, \mathbf{1 0}$ & $C_{3 \mathrm{v}}$ & -64.9 & -21.6 \\
\hline cyclo- $\mathrm{Cu}_{4}(\mu-\mathrm{H})_{4}(\mathrm{CO})_{3}, \mathbf{1 1}$ & $C_{2 \mathrm{v}}$ & -25.8 & -8.6 \\
\hline $\mathrm{Cu}_{4}(\mu-\mathrm{H})_{4}(\mathrm{CO})_{4}, \mathbf{1 2}$ & $T_{\mathrm{d}}$ & -87.2 & -21.8 \\
\hline cyclo- $\mathrm{Cu}_{4}(\mu-\mathrm{H})_{4}(\mathrm{CO})_{4}, \mathbf{1 3}$ & $D_{2 \mathrm{~d}}$ & -33.4 & -8.3 \\
\hline cyclo- $\mathrm{Cu}_{4}(\mu-\mathrm{H})_{4}(\mathrm{CO})_{4}, \mathbf{1 4}$ & $D_{2 \mathrm{~h}}$ & -26.3 & -6.6 \\
\hline cyclo- $\mathrm{Cu}_{4}(\mu-\mathrm{H})_{4}\left(\mathrm{OH}_{2}\right), \mathbf{1 5}$ & $C_{\mathrm{s}}$ & -6.1 & -6.1 \\
\hline cyclo- $\mathrm{Cu}_{4}(\mu-\mathrm{H})_{4}\left(\mathrm{OH}_{2}\right)_{2}, \mathbf{1 6}$ & $C_{2 \mathrm{~h}}$ & -11.5 & -5.8 \\
\hline cyclo- $\mathrm{Cu}_{4}(\mu-\mathrm{H})_{4}\left(\mathrm{OH}_{2}\right)_{3}, 17$ & $C_{\mathrm{s}}$ & -12.4 & -4.1 \\
\hline $\mathrm{Cu}_{4}(\mu-\mathrm{H})_{4}\left(\mathrm{OH}_{2}\right)_{3}, \mathbf{1 8}$ & $C_{3}$ & -32.5 & -10.8 \\
\hline cyclo- $\mathrm{Cu}_{4}(\mu-\mathrm{H})_{4}\left(\mathrm{NH}_{3}\right), \mathbf{1 9}$ & $C_{\mathrm{s}}$ & -11.7 & -11.7 \\
\hline cyclo- $\mathrm{Cu}_{4}(\mu-\mathrm{H})_{4}\left(\mathrm{NH}_{3}\right)_{2}, \mathbf{2 0}$ & $C_{2 \mathrm{~h}}$ & -22.8 & -11.4 \\
\hline $\mathrm{Cu}_{4}(\mu-\mathrm{H})_{4}\left(\mathrm{NH}_{3}\right)_{4}, \mathbf{2 1}$ & $T_{\mathrm{d}}$ & -58.5 & -14.6 \\
\hline cyclo- $\mathrm{Cu}_{4}(\mu-\mathrm{H})_{4}\left(\mathrm{PH}_{3}\right), \mathbf{2 2}$ & $C_{\mathrm{s}}$ & -9.0 & -9.0 \\
\hline cyclo- $\mathrm{Cu}_{4}(\mu-\mathrm{H})_{4}\left(\mathrm{PH}_{3}\right)_{2}, \mathbf{2 3}$ & $C_{2 \mathrm{~h}}$ & -19.1 & -9.6 \\
\hline cyclo- $\mathrm{Cu}_{4}(\mu-\mathrm{H})_{4}\left(\mathrm{PH}_{3}\right)_{3}, \mathbf{2 4}$ & $C_{\mathrm{s}}$ & -19.7 & -6.6 \\
\hline $\mathrm{Cu}_{4}(\mu-\mathrm{H})_{4}\left(\mathrm{PH}_{3}\right)_{3}, 25$ & $C_{3 \mathrm{v}}$ & -51.2 & -17.1 \\
\hline cyclo- $\mathrm{Cu}_{4}(\mu-\mathrm{H})_{4}\left(\mathrm{PH}_{3}\right)_{4}, \mathbf{2 6}$ & $D_{2 \mathrm{~d}}$ & -22.0 & -5.5 \\
\hline $\mathrm{Cu}_{4}(\mu-\mathrm{H})_{4}\left(\mathrm{PH}_{3}\right)_{4}, 27$ & $T_{\mathrm{d}}$ & -66.8 & -16.7 \\
\hline
\end{tabular}

Footnotes: a). $\Delta E_{1}=E\left(\right.$ cyclo- $\left.\mathrm{Cu}_{4}(\mu-\mathrm{H})_{4} \mathrm{Nuc}_{\mathrm{n}}\right)-\left\{E\left[\right.\right.$ cyclo- $\left.\left.\mathrm{Cu}_{4}(\mu-\mathrm{H})_{4}\right]+\mathrm{n} E(\mathrm{Nuc})\right\}$.

It can be seen that all nucleophiles, Nuc, are loosely associated with the parent cyclo- $\mathrm{Cu}_{4}(\mu-\mathrm{H})_{4}$ molecule, the estimated interaction energies were found in the range of -0.8 to $-21.8 \mathrm{kcal} / \mathrm{mol}$. In particular, dinitrogen, $\mathrm{N}_{2}$, is the most loosely coordinated ligand with the $\mathrm{Cu}(\mathrm{I})$ centers, with interaction energies in the range of -0.8 to $-8.4 \mathrm{kcal} / \mathrm{mol}$. On the other hand, carbonyl, $\mathrm{CO}$, forms stronger $\mathrm{Cu}-\mathrm{CO}$ coordination bonds with bond energies in the range of -6.6 to -21.8 $\mathrm{kcal} / \mathrm{mol}$. The estimated $\mathrm{Cu}-\mathrm{OH}_{2}, \mathrm{Cu}-\mathrm{NH}_{3}$ and $\mathrm{Cu}-\mathrm{PH}_{3}$ bond energies were found in the ranges of -4.1 to $-6.1,-11.4$ to 14.6 and -5.5 to $-17.1 \mathrm{kcal} / \mathrm{mol}$, respectively. All nucleo- 
Table 2. The Hardness, $\eta$, and the Electrophilicity Index, $\omega$, of the cyclo- $\mathrm{Cu}_{4}(\mu-\mathrm{H})_{4} \mathrm{Nuc}_{\mathrm{n}}\left(\mathrm{n}=1-4\right.$; $\mathrm{Nuc}=\mathrm{N}_{2}, \mathrm{CO}$, $\mathrm{H}_{2} \mathrm{O}, \mathrm{NH}_{3}$ and $\mathrm{PH}_{3}$ ) Clusters Computed at the B3LYP/6-311+G(d,p) Level

\begin{tabular}{|c|c|c|}
\hline Cluster & $\begin{array}{c}\eta \\
{[\mathrm{eV}]}\end{array}$ & $\underset{[\mathrm{eV}]}{\boldsymbol{\omega}}$ \\
\hline cyclo $-\mathrm{Cu}_{4}(\mu-\mathrm{H})_{4}\left(\mathrm{~N}_{2}\right), \mathbf{1}$ & 2.15 & 2.12 \\
\hline cyclo $-\mathrm{Cu}_{4}(\mu-\mathrm{H})_{4}\left(\mathrm{~N}_{2}\right)_{2}, 2$ & 1.98 & 2.16 \\
\hline $\mathrm{Cu}_{4}(\mu-\mathrm{H})_{4}\left(\mathrm{~N}_{2}\right)_{3}, \mathbf{3}$ & 1.93 & 1.95 \\
\hline $\mathrm{Cu}_{4}(\mu-\mathrm{H})_{4}\left(\mathrm{~N}_{2}\right)_{4}, 4$ & 1.96 & 2.00 \\
\hline cyclo- $-\mathrm{Cu}_{4}(\mu-\mathrm{H})_{4}(\mathrm{CO}), \mathbf{5}$ & 1.98 & 2.47 \\
\hline cyclo $-\mathrm{Cu}_{4}(\mu-\mathrm{H})_{4}(\mathrm{CO})_{2}, 6$ & 1.85 & 2.52 \\
\hline cyclo $-\mathrm{Cu}_{4}(\mu-\mathrm{H})_{4}(\mathrm{CO})_{2}, 7$ & 1.92 & 2.52 \\
\hline $\mathrm{Cu}_{4}(\mu-\mathrm{H})_{4}(\mathrm{CO})_{2}, 8$ & 1.94 & 2.08 \\
\hline cyclo $-\mathrm{Cu}_{4}(\mu-\mathrm{H})_{4}(\mathrm{CO})_{3}, 9$ & 2.04 & 2.39 \\
\hline $\mathrm{Cu}_{4}(\mu-\mathrm{H})_{4}(\mathrm{CO})_{3}, \mathbf{1 0}$ & 1.96 & 2.19 \\
\hline cyclo- $\mathrm{Cu}_{4}(\mu-\mathrm{H})_{4}(\mathrm{CO})_{3}, 11$ & 1.72 & 2.59 \\
\hline $\mathrm{Cu}_{4}(\mu-\mathrm{H})_{4}(\mathrm{CO})_{4}, \mathbf{1 2}$ & 2.02 & 2.36 \\
\hline cyclo $-\mathrm{Cu}_{4}(\mu-\mathrm{H})_{4}(\mathrm{CO})_{4}, 13$ & 2.03 & 2.47 \\
\hline cyclo- $\mathrm{Cu}_{4}(\mu-\mathrm{H})_{4}(\mathrm{CO})_{4}, 14$ & 1.78 & 2.46 \\
\hline cyclo- $\mathrm{Cu}_{4}(\mu-\mathrm{H})_{4}\left(\mathrm{OH}_{2}\right), 15$ & 2.41 & 1.41 \\
\hline cyclo- $\mathrm{Cu}_{4}(\mu-\mathrm{H})_{4}\left(\mathrm{OH}_{2}\right)_{2}, 16$ & 2.24 & 1.22 \\
\hline cyclo- $\mathrm{Cu}_{4}(\mu-\mathrm{H})_{4}\left(\mathrm{OH}_{2}\right)_{3}, 17$ & 2.13 & 1.07 \\
\hline $\mathrm{Cu}_{4}(\mu-\mathrm{H})_{4}\left(\mathrm{OH}_{2}\right)_{3}, \mathbf{1 8}$ & 1.73 & 1.19 \\
\hline cyclo- $\mathrm{Cu}_{4}(\mu-\mathrm{H})_{4}\left(\mathrm{NH}_{3}\right), \mathbf{1 9}$ & 2.36 & 1.29 \\
\hline cyclo- $\mathrm{Cu}_{4}(\mu-\mathrm{H})_{4}\left(\mathrm{NH}_{3}\right)_{2}, \mathbf{2 0}$ & 2.15 & 1.04 \\
\hline $\mathrm{Cu}_{4}(\mu-\mathrm{H})_{4}\left(\mathrm{NH}_{3}\right)_{4}, \mathbf{2 1}$ & 1.44 & 0.68 \\
\hline cyclo $-\mathrm{Cu}_{4}(\mu-\mathrm{H})_{4}\left(\mathrm{PH}_{3}\right), 22$ & 2.34 & 1.53 \\
\hline cyclo $-\mathrm{Cu}_{4}(\mu-\mathrm{H})_{4}\left(\mathrm{PH}_{3}\right)_{2}, \mathbf{2 3}$ & 2.15 & 1.36 \\
\hline cyclo- $-\mathrm{Cu}_{4}(\mu-\mathrm{H})_{4}\left(\mathrm{PH}_{3}\right)_{3}, 24$ & 1.95 & 1.22 \\
\hline $\mathrm{Cu}_{4}(\mu-\mathrm{H})_{4}\left(\mathrm{PH}_{3}\right)_{3}, 25$ & 2.11 & 0.92 \\
\hline cyclo $-\mathrm{Cu}_{4}(\mu-\mathrm{H})_{4}\left(\mathrm{PH}_{3}\right)_{4}, \mathbf{2 6}$ & 2.09 & 1.04 \\
\hline $\mathrm{Cu}_{4}(\mu-\mathrm{H})_{4}\left(\mathrm{PH}_{3}\right)_{4}, 27$ & 2.12 & 0.84 \\
\hline
\end{tabular}

philes are more strongly bonded in the $3 \mathrm{D}$ than the planar or bent structures. Moreover, the bond energies increase upon increasing the number of the coordinated nucleophiles.

We have also computed the heat of formation of the $c y$ clo- $\mathrm{Cu}_{4}(\mu-\mathrm{H})_{4} \mathrm{Nuc}_{4}$ molecules upon tetramerization of their $\mathrm{HCuL}$ monomeric species according to the chemical equation:

\section{$4 \mathrm{HCuNuc} \rightarrow$ cyclo- $\mathrm{Cu}_{4}(\mu-\mathrm{H})_{4} \mathrm{Nuc}_{4}$}

It was found that all formation processes are exothermic indicating that these species could be isolated in their cyclic tetrameric form within a supersonic jet. The estimated formation energies were found to be $-76.3,-85.9,-45.1$ and $77.1 \mathrm{kcal} / \mathrm{mol}$ for the $\mathrm{Cu}_{4}(\mu-\mathrm{H})_{4}\left(\mathrm{~N}_{2}\right)_{4}, \mathrm{Cu}_{4}(\mu-\mathrm{H})_{4}(\mathrm{CO})_{4}$,
Table 3. The NICS Values (in ppm) Calculated at the Ring Center, NICS(0), 1.0 A Above the Ring Center, $\operatorname{NICS}(1)$ and the Corresponding zz-Components $\mathrm{NICS}_{\mathrm{zz}}(0)$ and $\mathrm{NICS}_{\mathrm{zz}}(1)$ of the Shielding Tensor Element, for the cyclo- $\mathrm{Cu}_{4}(\mu-\mathrm{H})_{4} \mathrm{Nuc}_{\mathrm{n}}(\mathrm{n}=1-4 ; \mathrm{Nuc}=$ $\mathrm{N}_{2}, \mathrm{CO}, \mathrm{H}_{2} \mathrm{O}, \mathrm{NH}_{3}$ and $\mathrm{PH}_{3}$ ) Molecules Computed at the GIAO/ B3LYP/6-311+G(d,p) Level

\begin{tabular}{|c|c|c|c|c|}
\hline Cluster & $\operatorname{NICS}(0)$ & $\operatorname{NICS}(1)$ & $\operatorname{NICS}_{z z}(0)$ & $\operatorname{NICS}_{z z}(1)$ \\
\hline cyclo $-\mathrm{Cu}_{4}(\mu-\mathrm{H})_{4}\left(\mathrm{~N}_{2}\right), \mathbf{1}$ & -6.9 & -3.1 & 12.5 & -0.5 \\
\hline cyclo $-\mathrm{Cu}_{4}(\mu-\mathrm{H})_{4}\left(\mathrm{~N}_{2}\right)_{2}, \mathbf{2}$ & -7.6 & -5.5 & 14.9 & -0.1 \\
\hline $\mathrm{Cu}_{4}(\mu-\mathrm{H})_{4}\left(\mathrm{~N}_{2}\right)_{3}, \mathbf{3}$ & -22.7 & - & - & - \\
\hline $\mathrm{Cu}_{4}(\mu-\mathrm{H})_{4}\left(\mathrm{~N}_{2}\right)_{4}, 4$ & -21.2 & - & - & - \\
\hline cyclo- $\mathrm{Cu}_{4}(\mu-\mathrm{H})_{4}(\mathrm{CO}), \mathbf{5}$ & -9.3 & -4.1 & 10.1 & -2.2 \\
\hline cyclo- $\mathrm{Cu}_{4}(\mu-\mathrm{H})_{4}(\mathrm{CO})_{2}, \mathbf{6}$ & -8.6 & -3.3 & 15.5 & -1.3 \\
\hline cyclo- $\mathrm{Cu}_{4}(\mu-\mathrm{H})_{4}(\mathrm{CO})_{2}, 7$ & -8.6 & -3.9 & 5.5 & -2.3 \\
\hline $\mathrm{Cu}_{4}(\mu-\mathrm{H})_{4}(\mathrm{CO})_{2}, \mathbf{8}$ & -22.4 & - & - & - \\
\hline cyclo- $\mathrm{Cu}_{4}(\mu-\mathrm{H})_{4}(\mathrm{CO})_{3}, 9$ & -9.9 & - & - & - \\
\hline $\mathrm{Cu}_{4}(\mu-\mathrm{H})_{4}(\mathrm{CO})_{3}, \mathbf{1 0}$ & -19.7 & - & - & - \\
\hline cyclo- $\mathrm{Cu}_{4}(\mu-\mathrm{H})_{4}(\mathrm{CO})_{3}, \mathbf{1 1}$ & - & - & - & - \\
\hline $\mathrm{Cu}_{4}(\mu-\mathrm{H})_{4}(\mathrm{CO})_{4}, \mathbf{1 2}$ & -17.4 & - & - & \\
\hline cyclo- $\mathrm{Cu}_{4}(\mu-\mathrm{H})_{4}(\mathrm{CO})_{4}, \mathbf{1 3}$ & -10.7 & - & - & - \\
\hline cyclo- $\mathrm{Cu}_{4}(\mu-\mathrm{H})_{4}(\mathrm{CO})_{4}, \mathbf{1 4}$ & - & - & - & - \\
\hline cyclo- $\mathrm{Cu}_{4}(\mu-\mathrm{H})_{4}\left(\mathrm{OH}_{2}\right), \mathbf{1 5}$ & -6.9 & -3.1 & 12.2 & -0.7 \\
\hline cyclo- $\mathrm{Cu}_{4}(\mu-\mathrm{H})_{4}\left(\mathrm{OH}_{2}\right)_{2}, \mathbf{1 6}$ & -7.0 & -2.9 & 14.3 & -0.1 \\
\hline cyclo- $\mathrm{Cu}_{4}(\mu-\mathrm{H})_{4}\left(\mathrm{OH}_{2}\right)_{3}, 17$ & -6.9 & -3.2 & 12.6 & -0.3 \\
\hline $\mathrm{Cu}_{4}(\mu-\mathrm{H})_{4}\left(\mathrm{OH}_{2}\right)_{3}, \mathbf{1 8}$ & -16.0 & - & - & - \\
\hline cyclo- $\mathrm{Cu}_{4}(\mu-\mathrm{H})_{4}\left(\mathrm{NH}_{3}\right), \mathbf{1 9}$ & -7.0 & -3.1 & 12.3 & -0.8 \\
\hline cyclo- $\mathrm{Cu}_{4}(\mu-\mathrm{H})_{4}\left(\mathrm{NH}_{3}\right)_{2}, \mathbf{2 0}$ & -7.2 & -2.7 & 16.2 & 0.1 \\
\hline $\mathrm{Cu}_{4}(\mu-\mathrm{H})_{4}\left(\mathrm{NH}_{3}\right)_{4}, \mathbf{2 1}$ & -20.7 & - & - & - \\
\hline cyclo- $\mathrm{Cu}_{4}(\mu-\mathrm{H})_{4}\left(\mathrm{PH}_{3}\right), \mathbf{2 2}$ & -6.8 & -3.0 & 13.0 & -0.5 \\
\hline cyclo- $\mathrm{Cu}_{4}(\mu-\mathrm{H})_{4}\left(\mathrm{PH}_{3}\right)_{2}, \mathbf{2 3}$ & -7.1 & -2.7 & 16.9 & 0.2 \\
\hline cyclo- $\mathrm{Cu}_{4}(\mu-\mathrm{H})_{4}\left(\mathrm{PH}_{3}\right)_{3}, \mathbf{2 4}$ & -6.7 & -3.0 & 13.2 & -0.2 \\
\hline $\mathrm{Cu}_{4}(\mu-\mathrm{H})_{4}\left(\mathrm{PH}_{3}\right)_{3}, \mathbf{2 5}$ & -17.8 & - & - & - \\
\hline cyclo- $\mathrm{Cu}_{4}(\mu-\mathrm{H})_{4}\left(\mathrm{PH}_{3}\right)_{4}, \mathbf{2 6}$ & -8.0 & -3.9 & 10.5 & 2.6 \\
\hline $\mathrm{Cu}_{4}(\mu-\mathrm{H})_{4}\left(\mathrm{PH}_{3}\right)_{4}, 27$ & -14.5 & - & - & - \\
\hline
\end{tabular}

$\mathrm{Cu}_{4}(\mu-\mathrm{H})_{4}\left(\mathrm{NH}_{3}\right)_{4}$ and $\mathrm{Cu}_{4}(\mu-\mathrm{H})_{4}\left(\mathrm{PH}_{3}\right)_{4}$ complexes, respectively. It is worth to be noticed that fully substituted complexes involving the $\mathrm{OH}_{2}$ nucleophile was not possible to be located on the PES either as local minima or saddle points.

3.3. The Hardness and Electrophilicity of the cyclo$\mathrm{Cu}_{4}(\mu-\mathrm{H})_{4} \mathrm{Nuc}_{\mathrm{n}}\left(\mathrm{n}=1-4 ; \mathrm{Nuc}=\mathrm{N}_{2}, \mathrm{CO}, \mathrm{H}_{2} \mathrm{O}, \mathrm{NH}_{3}\right.$ and $\left.\mathrm{PH}_{3}\right)$ Molecules

The hardness and electrophilicity parameters of the $c y$ clo- $\mathrm{Cu}_{4}(\mu-\mathrm{H})_{4} \mathrm{Nuc}_{\mathrm{n}}\left(\mathrm{n}=1-4 ; \mathrm{L}=\mathrm{N}_{2}, \mathrm{CO}, \mathrm{H}_{2} \mathrm{O}, \mathrm{NH}_{3}\right.$ and $\mathrm{PH}_{3}$ ) molecules are compiled in Table 2. 

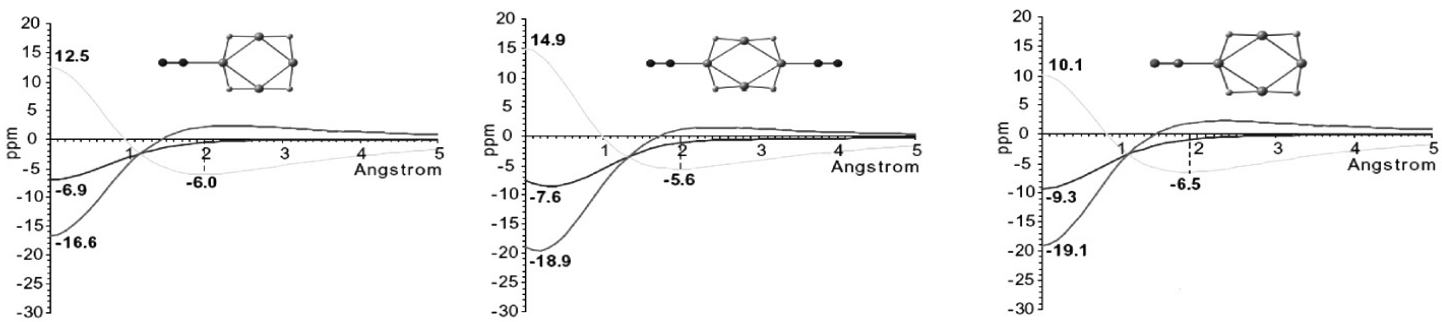

$1\left(C_{2 v}\right)$

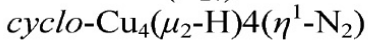

$2\left(D_{2 \mathrm{~h}}\right)$
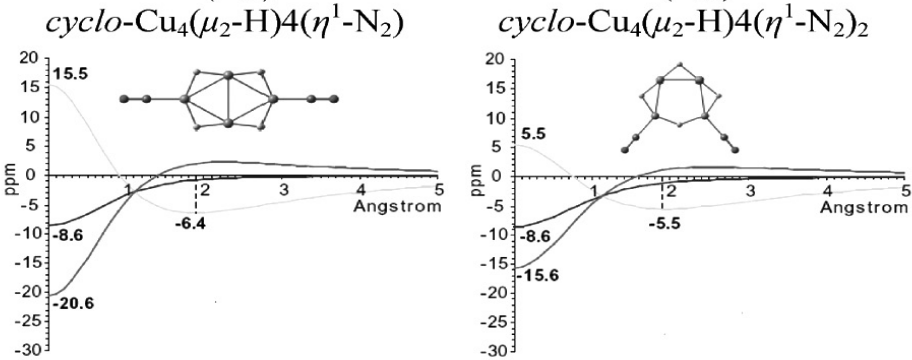

$6\left(D_{2 \mathrm{~h}}\right)$ cyclo- $\mathrm{Cu}_{4}\left(\mu_{2}-\mathrm{H}\right)_{4}\left(\eta^{1}-\mathrm{CO}\right)_{2}$

$7\left(C_{2 v}\right)$

cyclo $-\mathrm{Cu}_{4}\left(\mu_{2}-\mathrm{H}\right)_{4}\left(\eta^{1}-\mathrm{CO}\right)_{2}$

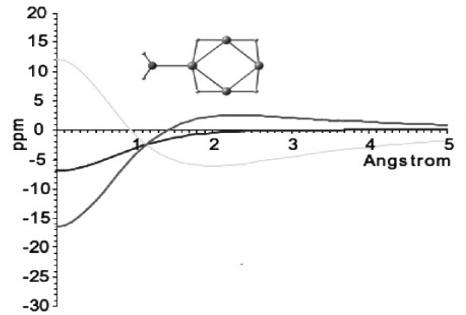

$15\left(C_{\mathrm{s}}\right)$

cyclo- $\mathrm{Cu}_{4}\left(\mu_{2}-\mathrm{H}\right)_{4}\left(\mathrm{OH}_{2}\right)$

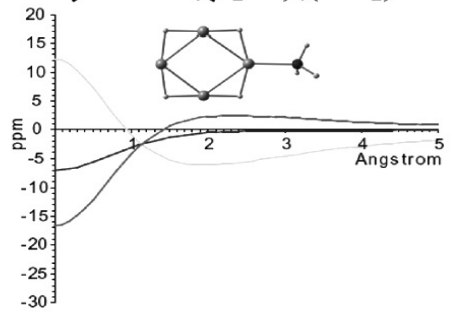

$18\left(C_{\mathrm{s}}\right)$

cyclo- $\mathrm{Cu}_{4}\left(\mu_{2}-\mathrm{H}\right)_{2}\left(\mu_{3}-\mathrm{H}\right)_{2}\left(\mathrm{NH}_{3}\right)$

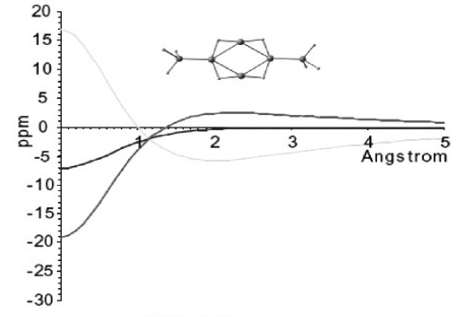

$22\left(C_{2 \mathrm{~h}}\right)$

cyclo- $\mathrm{Cu}_{4}\left(\mu_{2}-\mathrm{H}\right)_{4}\left(\mathrm{PH}_{3}\right)_{2}$

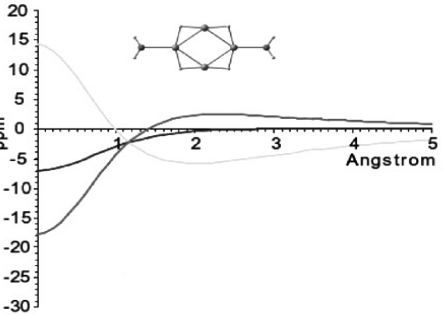

$16\left(C_{2 \mathrm{~h}}\right)$ cyclo- $-\mathrm{Cu}_{4}\left(\mu_{2}-\mathrm{H}\right)_{4}\left(\mathrm{OH}_{2}\right)_{2}$

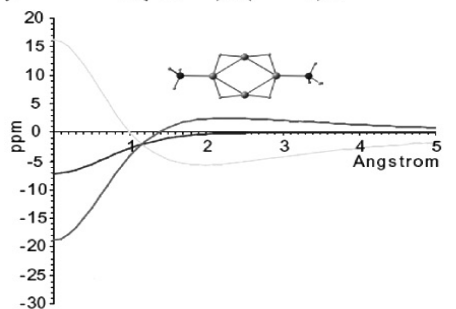

$19\left(C_{2 \mathrm{~h}}\right)$

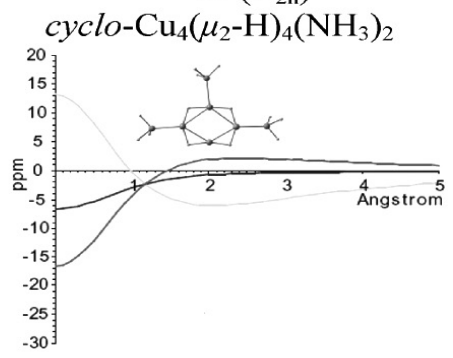

$23\left(C_{\mathrm{s}}\right)$

cyclo- $-\mathrm{Cu}_{4}\left(\mu_{2}-\mathrm{H}\right)_{4}\left(\mathrm{PH}_{3}\right)_{2}$
$5\left(C_{2 v}\right)$

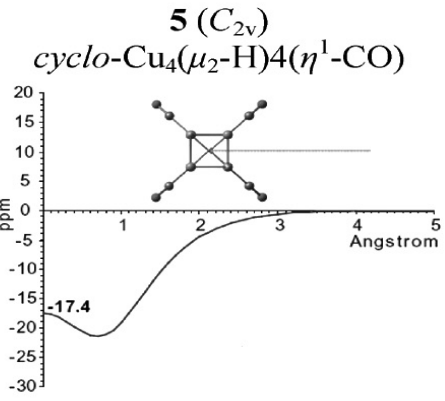

$10\left(C_{3 \mathrm{v}}\right)$ cyclo- $\mathrm{Cu}_{4}\left(\mu_{3}-\mathrm{H}\right)_{4}\left(\eta^{1}-\mathrm{CO}\right)_{3}$

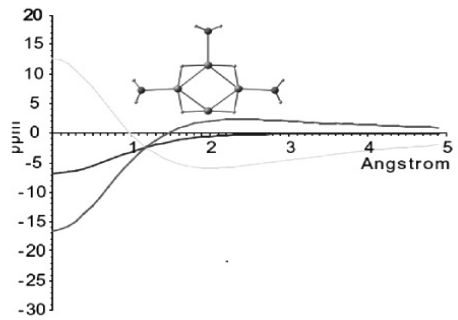

$17\left(C_{\mathrm{s}}\right)$
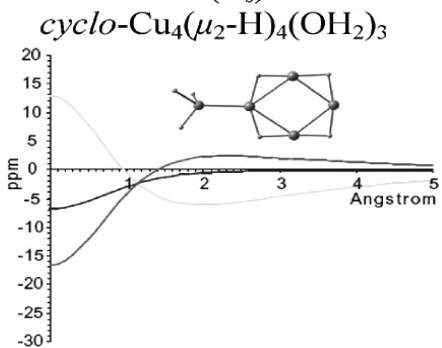

$21\left(C_{\mathrm{s}}\right)$

cyclo- $\mathrm{Cu}_{4}\left(\mu_{3}-\mathrm{H}\right)_{4}\left(\mathrm{PH}_{3}\right)$

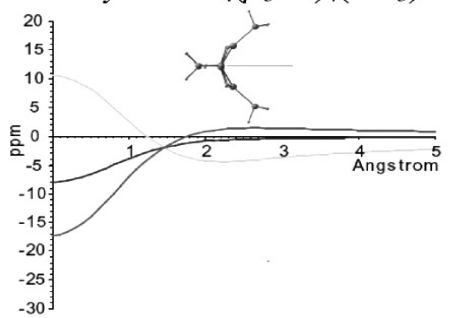

$25\left(D_{2 \mathrm{~d}}\right)$

cyclo- $\mathrm{Cu}_{4}\left(\mu_{2}-\mathrm{H}\right)_{4}\left(\mathrm{PH}_{3}\right)_{4}$

Fig. (3). The NICS scan pictures for the isotropic $\sigma^{\mathrm{iso}}(\mathrm{bq}) \_, \sigma^{\mathrm{zz}}\left(\mathrm{bq}_{\mathrm{out}}\right) \_$_ and $\sigma\left(\mathrm{bq}_{\mathrm{in}}\right) \_$_ tensors of representative $c y c l o-\mathrm{Cu} 4(\mu$ $\mathrm{H})_{4} \mathrm{Nuc}_{\mathrm{n}}\left(\mathrm{n}=1-4 ; \mathrm{Nuc}=\mathrm{N}_{2}, \mathrm{CO}, \mathrm{OH}_{2}, \mathrm{NH}_{3}, \mathrm{PH}_{3}\right)$ molecules computed at the B3LYP/6-311+G(d,p) level.

The high stability of the cyclo- $\mathrm{Cu}_{4}(\mu-\mathrm{H})_{4} \mathrm{~L}_{\mathrm{n}}(\mathrm{n}=1-4 ; \mathrm{L}=$ $\mathrm{N}_{2}, \mathrm{CO}, \mathrm{H}_{2} \mathrm{O}, \mathrm{NH}_{3}$ and $\mathrm{PH}_{3}$ ) molecules is also reflected on the estimated high values of hardness, $\eta$ defined as $\eta=$ $\left(\varepsilon_{\text {LUMO }}-\varepsilon_{\text {HOMO }}\right) / 2[21]$. Generally, according to the com- puted $\eta$ values the stability of the cyclo- $\mathrm{Cu}_{4}(\mu-\mathrm{H})_{4} \mathrm{~L}_{\mathrm{n}}$ molecules decreases upon increasing the degree of substitution. According to the hardness, the stability of the $c y c l o-\mathrm{Cu}_{4}(\mu$ - 
$\mathrm{H})_{4} \mathrm{~L}_{\mathrm{n}}$ molecules follows the trend: $\mathrm{H}_{2} \mathrm{O}>\mathrm{NH}_{3}>\mathrm{PH}_{3}>\mathrm{N}_{2}>$ CO.

The electrophilicity index $\omega$ (Table 2) computed [22] as $\omega=\mu^{2} / 2 \eta$, where $\mu$ and $\eta$ are the chemical potential and hardness respectively, given approximately by the expressions $\mu=\left(\varepsilon_{\text {LUMO }}+\varepsilon_{\text {HOMO }}\right) / 2$ and $\eta=\left(\varepsilon_{\text {LUMO }}-\varepsilon_{\text {HOMO }}\right)$ measures the electrophilic character of the four-member ring and consequently is a measure of the aromatic character of the ring. It can be seen that the electrophilicity decreases upon increasing substitution. The electrophilicity of the fourmember ring core structure follows the trend: $\mathrm{CO}>\mathrm{N}_{2}>\mathrm{PH}_{3}$ $>\mathrm{H}_{2} \mathrm{O}>\mathrm{NH}_{3}$. The lowering of the electrophilicity of the cyclo- $\mathrm{Cu}_{4}(\mu-\mathrm{H})_{4}\left(\mathrm{OH}_{2}\right)_{1-4}$ and cyclo- $\mathrm{Cu}_{4}(\mu-\mathrm{H})_{4}\left(\mathrm{NH}_{3}\right)_{1-4}$ species involving the pure $\sigma$-donor $\mathrm{H}_{2} \mathrm{O}$ and $\mathrm{NH}_{3}$ ligands could be attributed to the increase of the $\pi$-electron density on the four-membered $\mathrm{Cu}_{4}$ ring.

3.4. Aromacity/Antiaromaticity of the cyclo- $\mathrm{Cu}_{4}(\mu-\mathrm{H})_{4}$ $\mathrm{Nuc}_{\mathrm{n}}\left(\mathrm{n}=1-4\right.$; $\mathrm{Nuc}=\mathrm{N}_{2}, \mathrm{CO}, \mathrm{H}_{2} \mathrm{O}, \mathrm{NH}_{3}$ and $\left.\mathrm{PH}_{3}\right)$ Molecules

Planarity, high stability, bond length equalization and hardness are conventionally good indicators of aromaticity, but this is restrictive in many examples. In order to quantify the aromaticity/antiaromaticity of the clusters we applied the magnetic criterion, viz. nucleus-independent chemical shift (NICS), proposed by Schleyer et al. [20]. Negative (diatropic) NICS values indicate aromaticity, while positive (paratropic) values imply antiaromaticity. $\operatorname{NICS}(0)$ is usually computed at the ring centers, but also can be calculated at certain distance above or below the center of the ring; the NICS obtained at $1 \AA$ above the ring centroid, NICS(1) as well as the $\mathrm{NICS}_{\mathrm{zz}}(1)$ tensor component are considered to be better aromaticity indices than $\operatorname{NICS}(0)$ [23,24]. The $\operatorname{NICS}(0), \operatorname{NICS}(1), \operatorname{NICS}_{z z}(0)$ and $\operatorname{NICS}_{z z}(1)$ are given in Table 3.

To get a better insight into the origin of the aromaticity of the cyclo- $\mathrm{Cu}_{4}(\mu-\mathrm{H})_{4} \mathrm{Nuc}_{\mathrm{n}}\left(\mathrm{n}=1-4 ; \mathrm{Nuc}=\mathrm{N}_{2}, \mathrm{CO}, \mathrm{H}_{2} \mathrm{O}, \mathrm{NH}_{3}\right.$ and $\mathrm{PH}_{3}$ ) molecules we applied the recently proposed NICS scan procedure, which is based on scanning the NICS, $\sigma(\mathrm{bq})$, values over a distance $R$ and dissecting them into in-plane, $\sigma^{\text {iso }}\left(\mathrm{bq}_{\text {in }}\right)$ and out-of-plane, $\sigma^{\mathrm{zz}}\left(\mathrm{bq}_{\text {out }}\right)$ components $[25,26]$. The NICS scan pictures for the isotropic $\sigma^{\mathrm{iso}}(\mathrm{bq}), \sigma^{\mathrm{zz}}\left(\mathrm{bq}_{\mathrm{out}}\right)$, and $\sigma\left(\mathrm{bq}_{\mathrm{in}}\right)$ tensors of representative molecules are given in Fig. (3).

It can be seen that all cyclo- $\mathrm{Cu}_{4}(\mu-\mathrm{H})_{4} \mathrm{Nuc}_{\mathrm{n}}(\mathrm{n}=1-4$; Nuc $=\mathrm{N}_{2}, \mathrm{CO}, \mathrm{H}_{2} \mathrm{O}, \mathrm{NH}_{3}$ and $\mathrm{PH}_{3}$ ) molecules exhibit negative NICS $(0)$ values, only slightly affected by the degree of substitution. On the other hand, the aromaticity of the 3D tetrahedral $\mathrm{Cu}_{4}$ core structures, the so-called spherical aromaticity, is higher than the aromaticity of the isomeric planar structures. Noteworthy is the antiaromaticity of all planar rings suggested by the positive $\operatorname{NICS}_{z z}(0)$ values. The $\operatorname{NICS}_{z z}(1)$ values become negative, but very small suggestive of non aromaticity for these systems. However, the NICS component acquires negative values (in the range of -5.6 to $-10.5 \mathrm{ppm}$ ) in a distance of $1.6-1.8 \AA$ above the ring plane. Considering that the $\mathrm{NICS}_{\mathrm{zz}}$ component is a better index of aromaticity $[23,24]$ we could say that all planar structures keep the aromatic character of the parent cyclo $-\mathrm{Cu}_{4}(\mu-\mathrm{H})_{4}$ molecule.

\section{CONCLUSIONS}

The results can be summarized as follows:

Successive nucleophilic attack of the parent aromatic cyclo- $\mathrm{Cu}_{4}(\mu-\mathrm{H})_{4}$ molecule by a series of nucleophiles affords novel cyclo- $\mathrm{Cu}_{4}(\mu-\mathrm{H})_{4} \mathrm{Nuc}_{\mathrm{n}}\left(\mathrm{n}=1-4 ; \mathrm{Nuc}=\mathrm{N}_{2}, \mathrm{CO}, \mathrm{H}_{2} \mathrm{O}\right.$, $\mathrm{NH}_{3}$ and $\mathrm{PH}_{3}$ ) clusters. Depending on the nature of the nucleophile and the degree of substitution, the cyclo- $\mathrm{Cu}_{4}(\mu-$ $\mathrm{H})_{4} \mathrm{Nuc}_{\mathrm{n}}$ clusters adopt planar, bent or 3D tetrahedral geometries. The 3D structures are obtained for the higher degrees of substitution, that is in the $\mathrm{Cu}_{4}(\mu-\mathrm{H})_{4} \mathrm{Nuc}_{\mathrm{n}}(\mathrm{n}=3,4$; $\mathrm{Nuc}=\mathrm{N}_{2}, \mathrm{CO}, \mathrm{H}_{2} \mathrm{O}, \mathrm{NH}_{3}$ and $\mathrm{PH}_{3}$ ) molecules.

All cyclo- $\mathrm{Cu}_{4}(\mu-\mathrm{H})_{4} \mathrm{Nuc}_{\mathrm{n}}\left(\mathrm{n}=1-4 ; \mathrm{Nuc}=\mathrm{N}_{2}, \mathrm{CO}, \mathrm{H}_{2} \mathrm{O}\right.$, $\mathrm{NH}_{3}$ and $\mathrm{PH}_{3}$ ) molecules are predicted to be bound with respect to their dissociation according to the following dissociation pattern:

cyclo- $\mathrm{Cu}_{4}(\mu-\mathrm{H})_{4} \mathrm{Nuc}_{\mathrm{n}} \rightarrow$ cyclo- $\mathrm{Cu}_{4}(\mu-\mathrm{H})_{4}+\mathrm{nNuc}$

The strength of the M-Nuc association follows the trend: $\mathrm{NH}_{3}>\mathrm{CO}>\mathrm{PH}_{3}>\mathrm{H}_{2} \mathrm{O}>\mathrm{N}_{2}$. The computed bond dissociation energies for the $\mathrm{Cu}-\mathrm{Nuc}$ bonds span the range of -0.8 to $-21.8 \mathrm{kcal} / \mathrm{mol}$.

The bonding of the cyclo- $\mathrm{Cu}_{4}(\mu-\mathrm{H})_{4} \mathrm{Nuc}_{\mathrm{n}}(\mathrm{n}=1-4 ; \mathrm{Nuc}=$ $\mathrm{N}_{2}, \mathrm{CO}, \mathrm{H}_{2} \mathrm{O}, \mathrm{NH}_{3}$ and $\mathrm{PH}_{3}$ ) molecules is characterized by a common ring-shaped electron density, which is constructed by highly delocalized $\sigma, \pi$ - and $\delta$-type MOs ( $s$ and $d$ orbital aromaticity). All cyclo- $\mathrm{Cu}_{4}(\mu-\mathrm{H})_{4} \mathrm{Nuc}_{\mathrm{n}}$ molecules in their planar, bent and $3 \mathrm{D}$ tetrahedral structures exhibit negative NICS $(0)$ values, and therefore keep the aromatic character of the parent cyclo- $\mathrm{Cu}_{4}(\mu-\mathrm{H})_{4}$ molecule.

\section{ACKNOWLEDGEMENTS}

This work was sponsored by the Greek Ministry of Education (EPEAK, PYTHAGORAS II, Project 77).

\section{REFERENCES}

[1] (a) A. C. Tsipis, and C. A. Tsipis, "Hydrometal Analogues of Aromatic Hydrocarbons: A New Class of Cyclic Hydrocoppers(I)", $J$. Am. Chem. Soc., vol. 125, pp. 1136-1137, February 2003. (b) C. A. Tsipis, E. E. Karagiannis, P. F. Kladou, and A. C. Tsipis, "Aromatic Gold and Silver 'Rings': Hydrosilver(I) and Hydrogold(I) Analogues of Aromatic Hydrocarbons", J. Am. Chem. Soc., vol. 126, pp. 12916-12929, October 2004. (c) A. C. Tsipis, and C. A. Tsipis, "Ligand-Stabilized Aromatic Three-Membered Gold Rings And Their Sandwichlike Complexes", J. Am. Chem. Soc., vol. 127, pp. 10623-10638, August 2005. (d) C. A. Tsipis, "DFT study of 'all-metal' aromatic compounds", Coord. Chem. Rev., vol. 249, pp. 2740-2762, December 2005.

[2] V. W. W. Yam, W. K.-M. Fung, and K.-K. Cheung, "Luminecence Behavior of Polynuclear Alkynylcopper(I) Phosphines", J. Cluster Sci., vol. 10, pp. 37-69, March 1999.

[3] M. M. Olmstead, and P. P. Power, "Isolation and first structural characterization of dimethyl sulfide solvates of phenyllithium, phenylcopper, and lower and higher order lithium phenylcuprate reagents", J. Am. Chem. Soc., vol. 112, pp. 8008-8014, October 1990.

[4] B. Lenders, D. M. Grove, W. J. J. Smeets, P. van der Sluis, A. L. Spek, and G. van Koten, "Use of dimethyl sulfide in organocopper chemistry: X-ray crystal structures of cyclo-tetrakis $(\mu$-2-methylphenyl)bis(dimethy lsulfide)tetracopper(I) and of the Polymeric copper bromide adduct bromo(dimethyl sulfide)copper(I)", Organometallics, vol. 10, pp. 786-791, March 1991.

[5] E. M. Meyer, S. Gambarotta, C. Floriani, A. Chiesi-Villa, and C. Guastinit, "Polynuclear aryl derivatives of group 11 metals: synthesis solid state-solution structural relationship, and reactivity with phosphines", Organometallics, vol. 8, pp. 1067-1079, April 1989. B. Schiemenz, and P. P. Power, "Synthesis of sterically encumbered terphenyls and characterization of their metal derivatives 
$\mathrm{Et}_{2} \mathrm{OLiC}_{6} \mathrm{H}_{3}-2,6-$ Trip $_{2}$ and $\mathrm{Me}_{2} \mathrm{SCuC}_{6} \mathrm{H}_{3}-2,6$-Trip 2 (Trip = 2,4,6-i$\left.\mathrm{Pr}_{3} \mathrm{C}_{6} \mathrm{H}_{2}^{-}\right)$"), Organometallics, vol. 15, pp. 958-964, February 1996.

[7] H. Eriksson, and M. Håkansson, "Mesitylcopper: Tetrameric and Pen-tameric", Organometallics, vol. 16, pp. 4243-4244, September 1997.

[8] H. Eriksson, M. Örtendhal, and M. Håkansson, "Arylmagnesium to Arylcopper Conversion Monitored by Solid State Characterization of Halide Intermediates. Synthesis of Homoleptic (o-Vinylphenyl) copper", Organometallics, vol. 15, pp. 4823-4831, October 1996.

[9] M. Håkansson, H. Eriksson, and S. Jagner, "Pentamethylphenylcopper(I): a square-planar tetranuclear cluster", Inorg. Chim. Acta, vol. 277, pp. 233-236, August 1998.

[10] M. Håkansson, H. Eriksson, B. A. Å̀hman, and S. Jagner, "Tetrameric trienylcopper and pentanuclear trienylcuprate", J. Organomet. Chem., vol. 595, pp. 102-108, January 2000.

[11] M. Håkansson, H. Eriksson, and S. Jagner, “Tetranuclear Homoleptic copper and silver aryls: 2,4,6-Triethylphenylcopper and 2,4,6triethylphenylsilver", Inorg. Chim. Acta, vol. 359, pp. 2519-2524, May 2006.

[12] P. L. Stiles, and R. E. Miller, "Structures and Bonding Nature of Small Monoligated Copper Clusters $\left(\mathrm{HCN}-\mathrm{Cu}_{\mathrm{n}}, \mathrm{n}=1-3\right)$ through High-Resolution Infrared Spectroscopy and Theory", J. Phys. Chem. A, vol. 110, pp. 10225-10235, August 2006.

[13] X.-J. Liu, X. Zhang, K.-L. Han, X.-P. Xing, S.-T. Sun, and Z.-C. Tang, "Experimental and Theoretical Study on the Structure and Formation Mechanism of $\left[\mathrm{C}_{6} \mathrm{H}_{5} \mathrm{Cu}_{\mathrm{m}}\right]^{-}(\mathrm{m}=1-3)$ ", J. Phys. Chem. A, vol. 111, pp. 3248, May 2007.

[14] M. J. Frisch, G. W. Trucks, H. B. Schlegel, et al., Gaussian 03, revision A1; Gaussian, Inc.: Pittsburgh, PA, 2003.

[15] A. D. Becke, "Density-functional thermochemistry. I. The effect of the exchange-only gradient correction", J. Chem. Phys., vol. 96, pp. 2155-2160, February 1992.

[16] A. D. Becke, "Density-functional thermochemistry. III. The role of exact exchange"J. Chem. Phys., vol. 98, pp. 5648-5652, April 1993.

[17] C. Lee, W. Yang, and R. G. Parr, "Development of the ColleSalvetti correlation-energy formula into a finctional of the electron density", Phys. Rev. B, vol. 37, pp. 785-789, January 1988.
[18] H. B. Schlegel, "Optimization of Equilibrium Geometries and Transition Structures", J. Comput. Chem., vol. 3, pp. 214-218, Summer 1982.

[19] J. Gauss, "Effects of electron correlation in the calculation of nuclear magnetic resonance chemical shifts" J. Chem. Phys., vol. 99, pp. 3629-3643, September 1993.

[20] P. V. R. Schleyer, C. Maerker, A. Dransfeld, H. Jiao, and N. J. R. v. R. Hommes, "Nucleus-Independent Chemical Shifts: A Simple and Efficient Aromaticity Probe", J. Am. Chem. Soc., vol. 118, pp. 6317-6318, July 1996.

[21] R. G. Pearson, "Absolute Electronegativity and Hardness Correlated with Molecular Orbital Theory", Proc. Natl. Acad. Sci. U.S.A., vol. 83, pp. 8440-8441, November 1986.

[22] R. G. Parr, L. v. Szentpaly, and S. Liu, "Electrophilicity Index", $J$. Am. Chem. Soc., vol. 121, pp. 1922-1924, March 1999.

[23] P. v. R. Schleyer, M. Monoharan, H. J. Jiao, and F. Stahl, "The Acenes: Is There a Relationship between Aromatic Stabilization and Reactivity?", Org. Lett., vol. 3, pp. 3643-3646, November 2001.

[24] C. Corminboeuf, T. Heine, G. Seifert, P. v. R. Schleyer, "Induced magnetic fields in aromatic [n]-annulenes-interpretation of NICS components", Phys. Chem. Chem. Phys., vol. 6, pp. 273-276, January 2004.

[25] (a) A. Stanger, "Nucleus-Independent Chemical Shifts (NICS): Distance Dependence and Revised Criteria for Aromaticity and Antiaromaticity", J. Org. Chem., vol. 71, pp. 883-893, February 2006. (b) A. Stanger, "Can Substituted Cyclopentadiene Become Aromatic or Antiaromatic?", Chem. Eur. J., vol. 12, pp. 2745-2751, March 2006.

[26] (a) J. Poater, J. M. Bofill, P. Alemany, and M. Solà, "Role of Electron Density and Magnetic Couplings on the Nucleus-Independent Chemical Shift (NICS) Profiles of [2.2]paracyclophane and Related Species", J. Org. Chem., vol. 71, pp. 1700-1702, February 2006. (b) J. O. C. Jiménez-Halla, E. Matito, J. Robles, and M. Solà, "Nucleus-independent chemical shift (NICS) profiles in a series of monocyclic planar inorganic compounds", J. Organometal. Chem., vol. 691, pp. 4359-4366, October 2006.

(C) Tsipis and Charistos; Licensee Bentham Open.

This is an open access article distributed under the terms of the Creative Commons Attribution License (http://creativecommons.org/licenses/by/2.5/), which permits unrestrictive use, distribution, and reproduction in any medium, provided the original work is properly cited. 